\title{
Foreign Policy Reasons and Economic Effect of the 1947 Monetary Reform in the USSR
}

\author{
Yuri Kropin \\ Department of Financial Markets and Banks \\ Financial University under the Government of the Russian Federation \\ Moscow, Russia \\ E-mail: kropin.yuri@yandex.ru
}

\begin{abstract}
The scope of research of this paper covers the monetary reform undertaken by the Soviet Union in December 1947. The target is to show that despite the Marxist statement of withering-away of money at the first stage of communist formation, the Soviet state attached a great importance to the development of the nation's institution of money. Besides, the monetary system of the USSR, as envisioned by the country's leadership, was expected to become the blueprint for the global social currency system as an alternative of the Bretton Woods system of monetary management. The author concludes that despite all efforts of the Soviet leadership to reform the monetary system, its effect was quite limited in the context of economic efficiency and had not lead to the establishment of the global social currency system. The survey method offers deductions and inductions, organic continuity of discussion, etc. The monetary system of the country offers the field of the corresponding results' application.
\end{abstract}

Keywords-money; monetary reform; currency assets; international monetary system; national economy

\section{INTRODUCTION}

Considering the monetary reform of 1947, researchers focus primarily on internal causes pertaining to the need to restore the war-ravaged national economy. And at the same time, the prerequisites for this reform, governed by the foreign-policy alignment of power balance in world economy, the necessity for payment settlement between the countries of the emerging world socialist system, remain without due consideration. The system's emergence inevitably determined its confrontation with the world capitalist system on all fronts, including currency relations.

How far did the stand-off between the West and the USSR tell on the post-war monetary reform? What role in the fate of the 1947 reform was played by the Bretton Woods Monetary and Financial Conference in 1944? Why didn't the USSR, the conference member, go towards the ratification of the conference decisions? Is it possible to consider the monetary reform of 1947 as a deliberate demonstration of the advantages of the socialist system; and if so, which of its parameters could, in the opinion of the Soviet authorities, be proof of this? The search for those questions lie at the heart of the paper.

\section{BRETTON-WOODS CONTEXT OF THE 1947 MONETARY REFORM}

The year 1947 was marked not only by the end of World War II, but also by the outbreak of the two global political and social systems' confrontation, one of which (capitalist) had a centuries-long record, but the second (socialist) just begun its formation. It seems clear that the leadership of the Soviet state did not have a clear understanding of how the new world system should be organized.

It was clear at that time the West, headed by the US, launched an overt confrontation with the USSR, with this new world social and political system that was forming around our country.

The monetary system presented one of the directions of such confrontment. The framework of that system, consonant with the US' interests, was laid at the Bretton Woods Monetary and Currency Conference as far back as the end of the war (July 1944). It was attended by the representatives of the Soviet Union. After weighing up, however, all the circumstances, the USSR did not ratify the conference decision, which, in spite of their relative reasonability, were evidently pro-American.

The validity of the conference decisions flew from the fact that near the end of the war $75 \%$ of the world monetary gold reserves concentrated in the territory of the USA [1]. Moreover, those were not only the US FRS reserves, but the reserves of a number of European countries involved in the Second World War as well. Germany was one of them.

Theoretical grounds for the decision reached by the said conference proceeded from the understanding then of the essence of money. In general, it came down to the fact that money is gold, and the number of monetary units indicated on banknotes issued by a Central Bank (CB), represented that metal. Correspondingly, banknotes presented the issuer's obligation on their unconditional redemption for gold - on banknote bearers' demand to a CB on the said conversion. The lack of necessary monetary gold reserves of almost all countries participating in the Bretton Woods Conference forced them to agree that their national currency would not represent gold, but American dollars, which in turn represented the real reserves of this metal. In essence, in 
many respects such Bretton Woods Conference decisions were analogous with the decisions of the Genoa Economic and Financial Conference in 1922. But the decisions of the later were applicable to the countries that won the First World War and the defeated countries (at that they addressed only domestic policy), whereas in contrast the Bretton Woods Conference decisions were applicable to the entire capitalist system, preparing for global stand-off with the Soviet Union, the new world sociopolitical system.

Obviously, if the USSR had ratified the conference decisions, in doing so it voluntarily recognized the capitalist system's superiority, whereas, according to the MarxistLeninist view of the world history, that system was to completely disappear in the historical perspective. Naturally, neither for ideological, no for political reasons the USSR could not join the new international monetary system. It had to create a corresponding system of its own, in which it was supposed to be the leader. To carry out that task it was necessary first to develop a relatively stable monetary system inside the country; for which purpose a monetary reform was devised and carried out in December 1947.

By that time, the Soviet Union for two years stopped buying defense equipment, food and other things abroad already; from the USA in the first instance. Earlies the above during the war time was purchased for gold mined in the country. Accordingly, for over two years after the war the country managed to augment its reserves of gold, which from the Marxist standpoint, adopted by the Communist Party of the Soviet Union (CPSU), presented "good" money. And as soon as the size of those reserves became more or less considerable, it became possible to implement the domestic monetary reform. The adequacy of the gold reserves in the State Bank of the USSR was determined by the asserted value of the Soviet ruble. Then it made about 0.2 $\mathrm{g}$ of gold.

True, it should be noted that this scale concerned foreigners rather than Soviet citizens. Citizens of the USSR were satisfied by reading just one of the inscriptions on banknotes, the denomination of which was ten rubles and more. That inscription read that the banknotes of the State Bank of the USSR were secured by the gold reserves and other assets. Soviet citizens could not even imagine that such banknotes could be exchanged for certain assets of the State Bank. In the meantime the latter had to carry out such exchange to foreigners. On the banknotes with a par value of one, three and five rubles there was a sign reading they were secured by all assets of the Union of the SSR.

Accordingly, the existence of two world systems will be accompanied by the existence of two global monetary systems.This, however, did not happen for quite a hackneyed reason - the lack of sufficient monetary gold reserves in the Soviet Union. If such a decision were made and the alternative international monetary system began functioning, then the USSR would have to mine gold not only on the number of currency units, indicated on Soviet banknotes of the nominal denomination, but also on the currency issue in all countries of the Communist bloc; while those countries, unlike most of the countries participating in the Bretton
Woods Conference, did not keep their gold reserves in the State Bank of the USSR. This was too much for a post-war country.

At that time the national economy was literally in ruins. The country itself needed gold reserves to buy machinery, equipment and other for restoration of the destroyed. This circumstance became the key for the fact that neither in 1947 nor in subsequent years an alternative conference was held to resolve the problem of a socialist monetary system's creation. In addition, according to the Marxist doctrine of building up Communism, money should have already died out at the first stage of its upbuilding. Having such "scientific" tenet, it was somewhat cumbersome to take a decision on the development of a socialist monetary system. Therefore, at that time the task was limited to the demonstration of a successful overcoming the aftereffects of the Great Patriotic War.

\section{THE MONETARY REFORM IN 1947 AS A DISPLAY OF SOCIALIST ECONOMIC SYSTEM'S “BENEFITS"}

The cancellation of food coupons was one of such demonstrative elements. The Soviet Union did this even right before the Great Britain, currency of which had also laid the foundation of the Bretton Woods monetary system and which, furthermore, had more colonies than any other European country. The internal vector of the monetary reform in 1947 came down, on the one hand, to the obscuration of the state's responsibility for the coupons' backing and, on the other hand, to demonstrating the country's transition to a peaceful economic life, where Soviet citizens were to independently set their family budgets and, therefore, be interested in a more productive labor. The wartime incentives were expected to be replaced by those of the peaceful life.

The monetary reform in 1947 in a way also sought a better convenience in goods' price tags. Although outwardly the reform was largely denominational; three zeros were erased from the banknotes and, accordingly, from price tags.

Besides, the reform partially targeted an ensured levelling of Soviet citizens' income. To a certain extent, the post-war monetary differentiation was caused by a quite unfair income generation by some war participants. During the wartime, soldiers and officers received money allowance, which in the conditions of warfare could be defrauded by someone at random. Often in the war there were times when chiefs of military units' financial department went missing with metal boxes containing monetary allowance. The 1947 reform provided the following. Savings in old monies kept on savings-bank books amounting from three to ten thousand rubles were exchanged with a $30 \%$ cutting, and those over ten thousand rubles were exchanged for only $50 \%$ of the previous amount.Effectively, Soviet citizens' property differentiation smoothed over, quite satisfying the ideological basics of Communism upbuilding, according to which, everyone is equal in capital goods, and where all are considered "equal co-owners of those goods" [2].

It should be said that the realization of the reform was met approvingly by the commonwealth.It was not an 
ostensible but actual approval because it (reform) was somewhat liberating the living conditions of the people. They were able to relatively freely go shopping, making their choice in favor of one or another commodity product those days; they in principle were able to buy land plots for their future homes, etc. While it is understandable that the overwhelming majority of the nation had limited funds, and the product range in socialist stores was very scarce in those days. It was necessary, however, to start with something economic reforms in peacetime.

In the context of present day, it is obvious that despite certain positive results of the reform, it could not give the same effect as, for example, in the post-war Western Germany that also began its reforms with the introduction of a new Bundesmark and a relative levelling of burgers' property differentiation [3]. Together with the Bundesmark, Germany had the freedom of private enterprise, competition and other attributes of marketplace. These factors could not but produce a weightier result than the monetary reform in our country. This became noticeable, however, not immediately, but only after a while. Immediately after the war the team spirit and the habit to overcome difficulties "en masse" had plaid their role in enthusiasm, demonstrated during the post-war economic recovery. However, progressively as the zeal was fading away, a lag in the two world systems' economic rivalry became more and more visible.

According to an indirect information, by the end of his life I.V. Stalin began to see those obvious things and wanted to reform, beside the monetary, many other systems. He did not do this, however, not because of his age or many processes' inertness, but inasmuch as it was impossible to transform the new world system without revising its fundamental ideological positions. And the fact that after the death of the leader of world proletariat that system continued to live for almost 40 years was a miracle, based on the national natural wealth and a Soviet man's ability to endure economic hardships of his life, and, of course, on a fair punitive machine of the Central Committee of the Communist Party of the Soviet Union. In sum, in the context of that time, it was impossible to reverse the situation in economy to the good by mere monetary reform.

"Social enterprises were not owners of available machinery, equipment, etc." [4]. Accordingly, they could not make independent decisions on production of something new, on drawing loans of the State Bank of the USSR against their innovative projects, etc. They were expected to merely target the set plan and suchlike. In such context, in principle, there could be no real substantial advance of the national economy. Under a rigid centralization various different-level projects could only be started and somehow carried out.Implementation of such projects at All-Russian (Komsomol) construction also prolonged the subsistence of the socialist management system for almost 70 years, which is quite a lot.

As to money, one of the positive effects of the socialist system's existence became both the "trust" in stable Soviet ruble and the development of domestic economists' ability to insightfully analyze different economic and market developments and processes, including money. That ability was developing owing to the absolute domination in the political economy and particular economic disciplines of the Marxist economic theory; while in the West economic science had an issue, on one hand, with the confrontation with the Socialist block and, on the other, with the resolution of quite applied problems concerning the realization of interests of particular circles. Consequently various schools of the Western economic science despite an external friction, were notable for apologetic and utilitarian principles. They showed no interest in the essence of money; they were invested in the use, augmenting and relatively rational cash distribution. The fact that the monetary reform in West Germany took a more successful effect, as compared with the 1947 monetary reform in our country, does not at all mean that Germany's economic science was at a higher level than of the Soviet Union.

It is a different matter that the Soviet economists' custom to insightfully analyze various economic and market phenomena, in particular, money, essentially, could not have a meaningful effect, since it was developing within a knowingly false doctrine - Marxism [5]. This doctrine, undoubtedly, was and remains the most landmark in economic science. While during the period of the 1947 monetary reform, the thought about its incapacity spelled an exile or execution. Absence of the possibility to freely and critically digest that doctrine did not also help to contribute to success of the said monetary reform.

\section{CONCLUSION}

To conclude, this reform left its contradictory mark in history of the country's economic life, but it could not have too profound positive implications. It was eventually superseded by the monetary reform in 1961 , leaving in the shadow all the specific nuances of the 1947 reform, many documents about which remain classified up to date.

\section{REFERENCES}

[1] Money, credit, banks: Textbook / E. A. Zvonovaya (ed.), Moscow: INFRA-m, 2012, p. 172.

[2] Fundamentals of economic knowledge. Manual for directors of political schools. Head of the team of contributors A. F. Rumyantsev, Moscow: Politizdat, 1972, p. 14.

[3] M. N. Ryndina, E. G Vasilevsky, V. V. Golosov et al, History of economic doctrines: Textbook for economists of specialized universities, Moscow: Higher School, 1983, pp. 454-456.

[4] Y. A. Kropin, Socialism and property. Report preprint, Moscow: Institute of Economics of the USSR Academy of Sciences, 1990, p. 5.

[5] Y. A. Kropin, Money and the contemporary monetary system. Moscow : RUSCIENCE, 2018, pp. 42-51. 